\title{
How females of Achtheinus spp. (Pandaridae: Siphonostomatoida) attach to their elasmobranch hosts with notes on their effects on the hosts' fins
}

\author{
Susan M. Dippenaar ${ }^{1}$ and Anine Jordaan ${ }^{2}$ \\ ${ }^{1}$ Department of Biodiversity, School of Molecular and Life Sciences, University of Limpopo, Sovenga, South Africa; \\ ${ }^{2}$ Laboratory for Electron Microscopy CRB, North-West University, Potchefstroom, South Africa
}

\begin{abstract}
Copepods of the genus Achtheinus Wilson, 1908 (Pandaridae) are parasites of elasmobranchs that attach to their fins, gill slits and around the nostrils. Specimens of Achtheinus pinguis Wilson, 1912 were collected and examined using histology and scanning electron microscopy to determine their way of attachment to the host and the possible effect on the host. They insert their antennae deep into the dermis of the shark's skin, which causes the most damage due to possible tissue compression and/or fibrosis as well as rupture of the connective tissue. Additionally, the presence of the copepod on the skin causes cell erosion of the epidermal cells and thus reduces the number of epidermal layers. The maxillipeds are used to attach to the placoid scales that cover the shark's skin and probably serve to keep the copepod and inserted antennae in position. This is accomplished by the insertion of the placoid scales into the flaccid corpus of the maxillipeds. Observed damage seems to be negligible to the shark apart from the possibility of secondary infection.
\end{abstract}

Keywords: Copepoda, attachment, Elasmobranchii, placoid scales, histology

Achtheinus Wilson, 1908 is a member of Pandaridae Milne-Edwards, 1840 with a widely debated taxonomic position and was synonymised with Perissopus Steenstrup and Lütken, 1861 by Cressey (1967). Achtheinus was resurrected by Ho (1975) based on the size of the dorsal plates of the second pedigerous somite compared to those of the succeeding two pairs, the two-segmented rami of the third pair of legs and the size of the caudal rami. However, all species were synonymised with A. oblongus Wilson, 1908, the type species of the genus. Izawa (2010) re-examined the previous nominal species of the genus and redescribed A. oblongus, A. dentatus Wilson, 1911 and A. pinguis Wilson, 1912.

The three species are morphologically very similar with very subtle differences in the length of the caudal rami, the stoutness and curvature of the antennal claw, the size and deflection of the posterior process of the maxilliped subchela and length and width of the protopod of leg 4 as well as those of the cephalic shield (Izawa 2010). These three species have been reported from a variety of elasmobranch hosts with $A$. oblongus restricted to the eastern Pacific Ocean off North America, A. dentatus restricted to the eastern Pacific off the Americas and A. pinguis reported from all three oceans (Izawa 2010).

The adult females of species of Achtheinus are mostly found on the fin edges, gill slits and around the nostrils of their hosts where they attach by deeply embedding their hook-like antennae into the skin (Ho 1975, Benz et al. 2003). However, the exact role of the subchelate maxillipeds, with their large, flaccid adhesion pad on the corpus in the attachment process is still unknown. In the present paper, results of a study on the role of the soft adhesion pads on the maxillipeds of $A$. pinguis in attaching to the placoid scales of the host are provided, together with notes on some effects of the deeply embedded antennae on the hosts' fins. Since the structure of the antennae and maxillipeds are mostly similar in the three Achtheinus species, it is expected that this will apply to all three species.

\section{MATERIALS AND METHODS}

Copepods were collected from a variety of host species caught in the shark nets off the KwaZulu-Natal coast of South Africa and from sharks caught during the Fisheries Branch of the Department of Agriculture, Forestry \& Fisheries's (DAFF) demersal cruises off the south and west coasts as well as from hosts caught by commercial fishermen off the west coast. Collected copepods were fixed and preserved in $70 \%$ ethanol and studied using the wooden slide technique (Humes and Gooding 1964) after being stained with a small amount of dissolved lignin pink in $70 \%$ ethanol. Adult $A$. pinguis females examined with stereo- and light microscopes and identified according to Izawa (2010) were selected from those collected from the fins of five Squalus cf. 

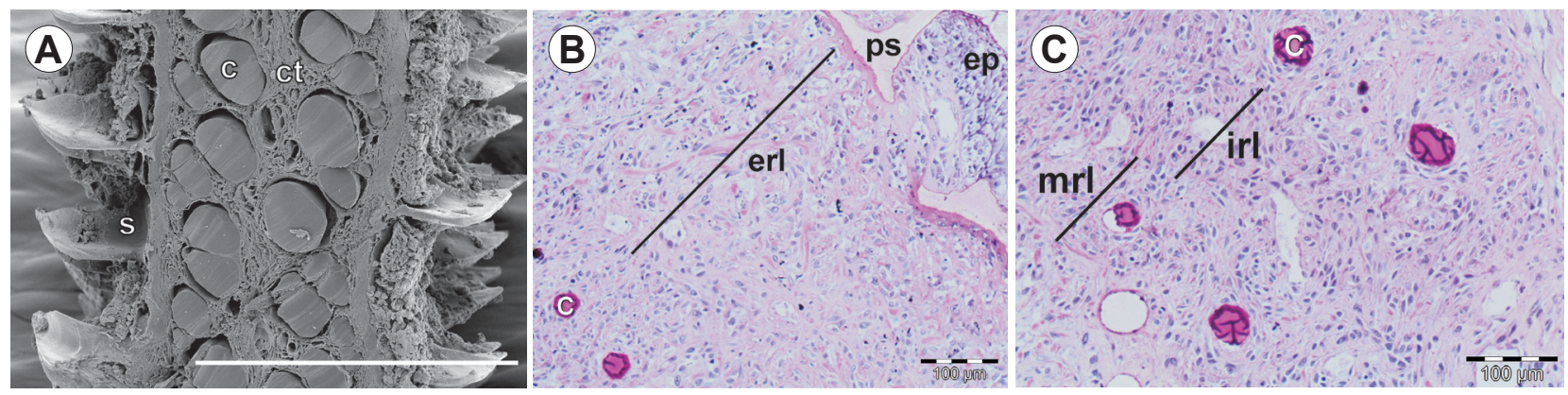

Fig. 1. A - scanning electron micrographs of a transverse section through the fin edge of Squalus cf. megalops showing the ceratotrichia (c), connective tissue (ct) and placoid scales (s); B - transverse section of the fin of Carcharias taurus with ceratotrichia (c), epidermis (ep) and external reticular layer (erl); $\mathbf{C}$ - transverse section of the fin of C. taurus with ceratotrichia (c), interior reticular layer (irl) and middle reticular layer $(\mathrm{mrl})$.

megalops (Macleay), 18 Galeorhinus galeus (Linnaeus) and four Carcharias taurus Rafinesque from the south and west coasts of South Africa (SA). Specimens selected for additional scanning electron microscopy were collected from the fin edges of C. taurus, S. cf. megalops and G. galeus also caught from the south and west coasts whereas specimens used for histological sections were collected from C. taurus from the southeast coast of SA and Carcharodon carcharias (Linnaeus) off the east coast of SA. Voucher specimens of A. pinguis (SAM A74024) are deposited in the Iziko South African Museum, Cape Town, South Africa.

A piece of $S$. cf. megalops fin cut off next to the attached copepods and three adult females were prepared for scanning electron microscopy by dehydrating them through a series of ethanol $(70,80,90,100,100 \%$ for one hour each) followed by immersion in hexamethyldisilazane. After complete evaporation of hexamethyldisilazane the specimens were sputter-coated with gold-palladium. Scanning electron microscopy was performed with a FEI Quanta 250 FEG SEM. Histological sections were made of pieces of fins of $C$. taurus and $C$. carcharias with a copepod attached. Material was first preserved in $70 \%$ ethanol and then dried through three replacements of $100 \%$ ethanol for 30 min each and two replacements of $100 \%$ LR White ${ }^{\mathrm{TM}}$ for one hour each. Thereafter, it was embedded in LR White ${ }^{\mathrm{TM}}$ resin and polymerised at $65^{\circ} \mathrm{C}$ overnight. Sections were stained with $0.5 \%$ aqueous toluidine blue followed by $0.05 \%$ aqueous neofuchsin. Anatomical terminology used conforms to Kabata (1979) and Huys and Boxshall (1991); host nomenclature is according to Froese and Pauly (2014).

\section{RESULTS}

\section{Anatomy of shark fins}

Shark fins are supported by ceratotrichia occurring in varying number of rows in different shark species (Fig. 1A,C). These dermal ceratotrichia are surrounded by ordinary connective tissue consisting of fibroblasts and a collagenous matrix (Fig. 1A-C). The fin dermis is divided into a papillary layer consisting of a thin layer of densely packed cells bordering the epidermis (Fig. 1B). The reticular layer is divided into three layers namely the exterior reticular layer, middle reticular layer and the interior reticular layer (Fig. 1B,C). The placoid scales are also embedded in the dermis but protrude through the epidermis

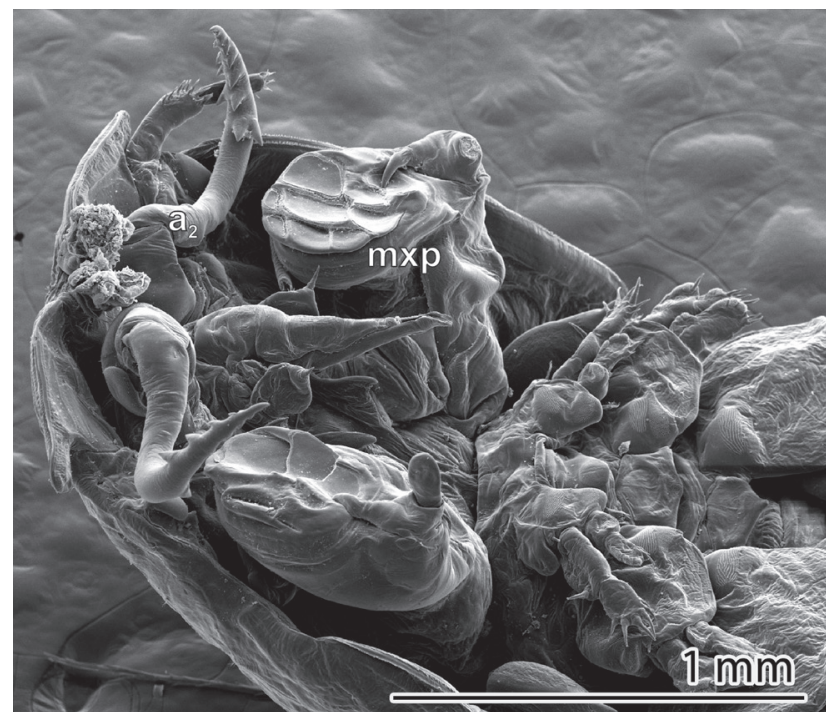

Fig. 2. Achtheinus pinguis from Squalus cf. megalops, adult female; SEM micrograph of ventral cephalothorax with antennae $\left(\mathrm{a}_{2}\right)$ and maxillipeds $(\mathrm{mxp})$.

(Fig. 1A,B) which consists of four to eight layers of cells (Fig. 1B).

\section{Attachment with antennae}

The antennae of species of Achtheinus (Fig. 2) are falciform with two rows of spikes on the terminal claw. These appendages are embedded deeply into the middle reticular layer of the dermis, consisting mostly of large fibre bundles and ceratotrichia (Fig. 3A), in order to attach the copepod firmly to the host. When the copepods are removed, the antennae often break off and the lesions caused to the host's skin are clearly visible (Fig. 3B,C), providing the opportunity for secondary infection. The epidermis layer of the skin, consisting of four to eight layers of cells on a strong basement membrane (Figs. 1B, 3D), appears disrupted and eroded underneath $A$. pinguis female with at places only one (possibly the monolayered stratum basale) to four layers (those of the stratum spinosum) still distinguishable (Fig. 3E). Comparing the dermal layers of the undamaged dermis (Fig. 1B,C) with those of the dermis where the antenna is inserted (Fig. 3A,B), signs of possible tissue com- 

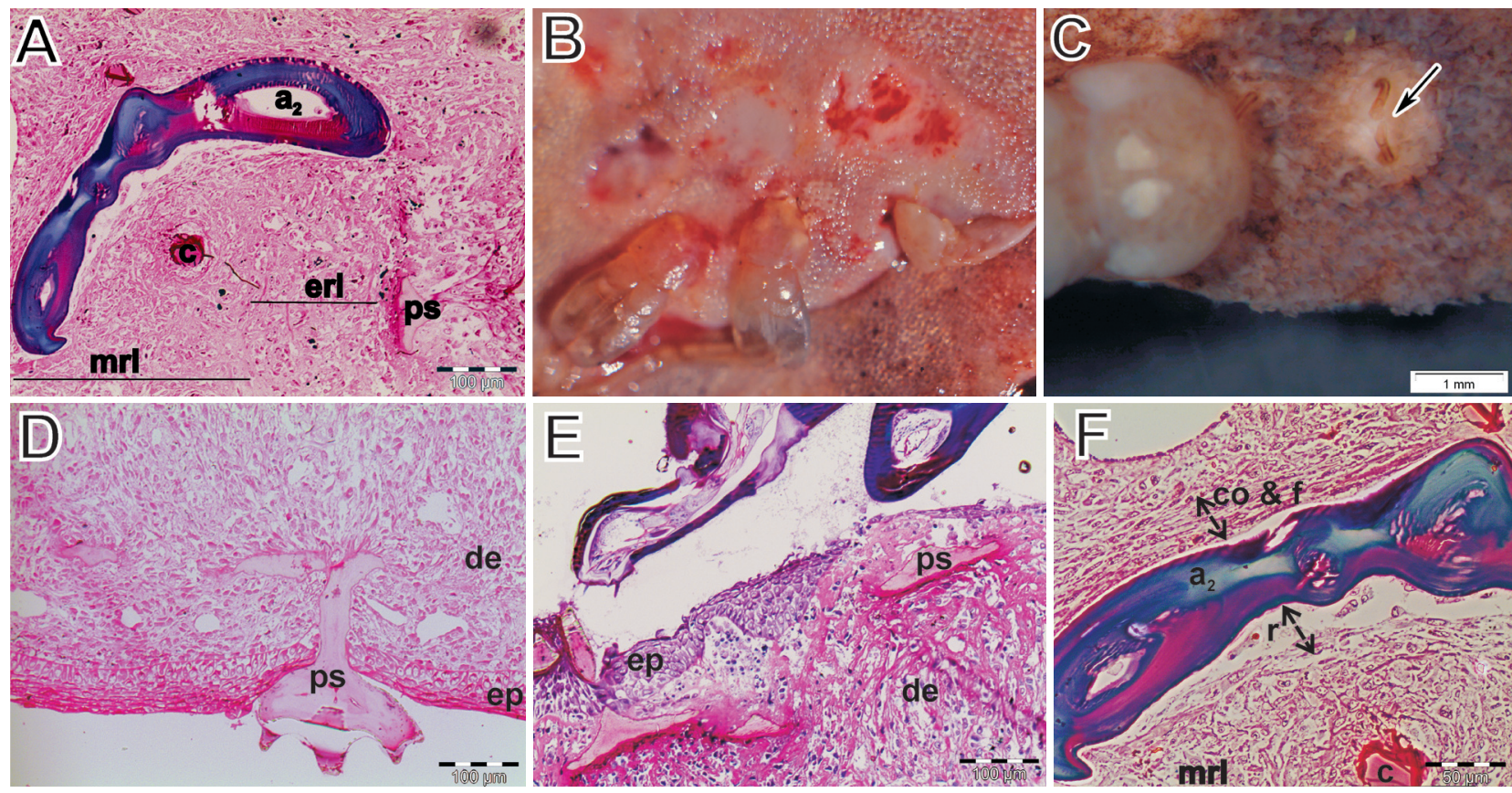

Fig. 3. Achtheinus pinguis, adult female. A - transverse section of female attached to host's fin with antenna deeply embedded into middle reticular layer of dermis of host's skin; B - lesions on host's fin caused by attached copepods; $\mathbf{C}$ - lesion (arrow) after removal of adult female with antennae broken off in dermis; D - transverse section through the host's skin with undamaged dermal layers, epidermal layers and placoid scale originating in the dermis; $\mathbf{E}$ - transverse section with the erosion of epidermal layers underneath copepod visible; $\mathbf{F}$ - antenna inserted into middle reticular layer of dermis with possible compression and or fibrosis and rupture of tissue visible. Abbreviations: $\mathrm{a}_{2}$ - antenna; c - ceratotrichia; co - compression; de - dermal layers/dermis; ep - epidermal layers/epidermis; erl - external reticular layer; $\mathrm{f}$ - fibrosis; $\mathrm{mrl}$ - middle reticular layer; $\mathrm{ps}$ - placoid scale; $\mathrm{r}$ - rupture of tissue.

pression or fibrosis are visible, especially next to the outer surface of the antenna (Fig. 3F), whereas the connective tissue seems to be ruptured next to the inner surface (with the two rows of spikes) (Fig. 3F).

\section{Female attachment with maxillipeds}

Scanning electron microscopy of the edges of the fin where individuals of $A$. pinguis attach reveals the structure of the placoid scales covering the skin, which are pointed posteriorly (Fig. 4A), but kite-shaped in dorsal view (Fig. 4B). The maxilliped of $A$. pinguis (Figs. 2, 4C) is subchelate, with a 'large flabby pad on the corpus', the subchela bearing a flattened posterior process with a seta at the base of the terminal claw. The placoid scales involved in the attachment of $A$. pinguis to the skin often remained attached to the copepod after being removed, indicating the security of the attachment mechanism. Examination of maxillipeds without placoid scales attached revealed the presence of longitudinal compressed kite-shaped openings on the corpus (Fig. 4D), which are similarly shaped to the kite-shapes of the placoid scales in dorsal view (Fig. 4B). These openings on the corpus seem to be remaining evidence of where the flaccid corpus was attached to the placoid scales (Fig. 4E).

Thus, the pointed part of the placoid scale is inserted into the flaccid corpus, which firmly wraps around it holding it into place (Fig. 4F). The function of the terminal claw (Fig. 4C,E,F) may be to determine the position for insertion and perhaps to keep the scale in position while the insertion into the corpus takes place or maybe also to determine the position of the pointed part of the scale (Fig. 4F) so that the copepod attaches facing the oncoming water. The function of the posterior process on the subchela (Fig. $4 \mathrm{C}, \mathrm{E}, \mathrm{F}$ ) is not clear.

\section{DISCUSSION}

The presence of placoid scales on sharks supports their fast swimming by reducing skin-friction drag in the turbulent water and is supposed to provide an added advantage of protection against ectoparasites (Meyer and Seegers 2012). However, the siphonostomatoid copepod of the genus Achtheinus evolved the ability to attach to the skin of sharks. This is done mainly by the antennae that are inserted deep into the dermis of the host (into the middle reticular layer), whereas the maxillipeds are used to attach to the placoid scales.

The presence of Achtheinus females on the skin of their elasmobranch hosts appears to have an adverse effect on the host as seen by the erosion and disruption of the epidermal layers. However, their presence does not seem to cause hyperplasia and compression of epidermal cells immediately underneath the copepod as seen in the infection of the interopercula of black drum, Pogonias cromis (Linnaeus), by Sciaenophilus tenuis van Beneden, 1855 (see Frasca et al. 2004). Even though hyperplasia of the epidermal layers as a result of copepod infection has been reported in elasmobranch gills (Benz 1980, Benz and Deets 1986, Benz and Adamson 1990, Borucinska and Benz 1999), it seems to be absent when the copepod attaches to the skin. However, apparent thickening of the host's skin surrounding 

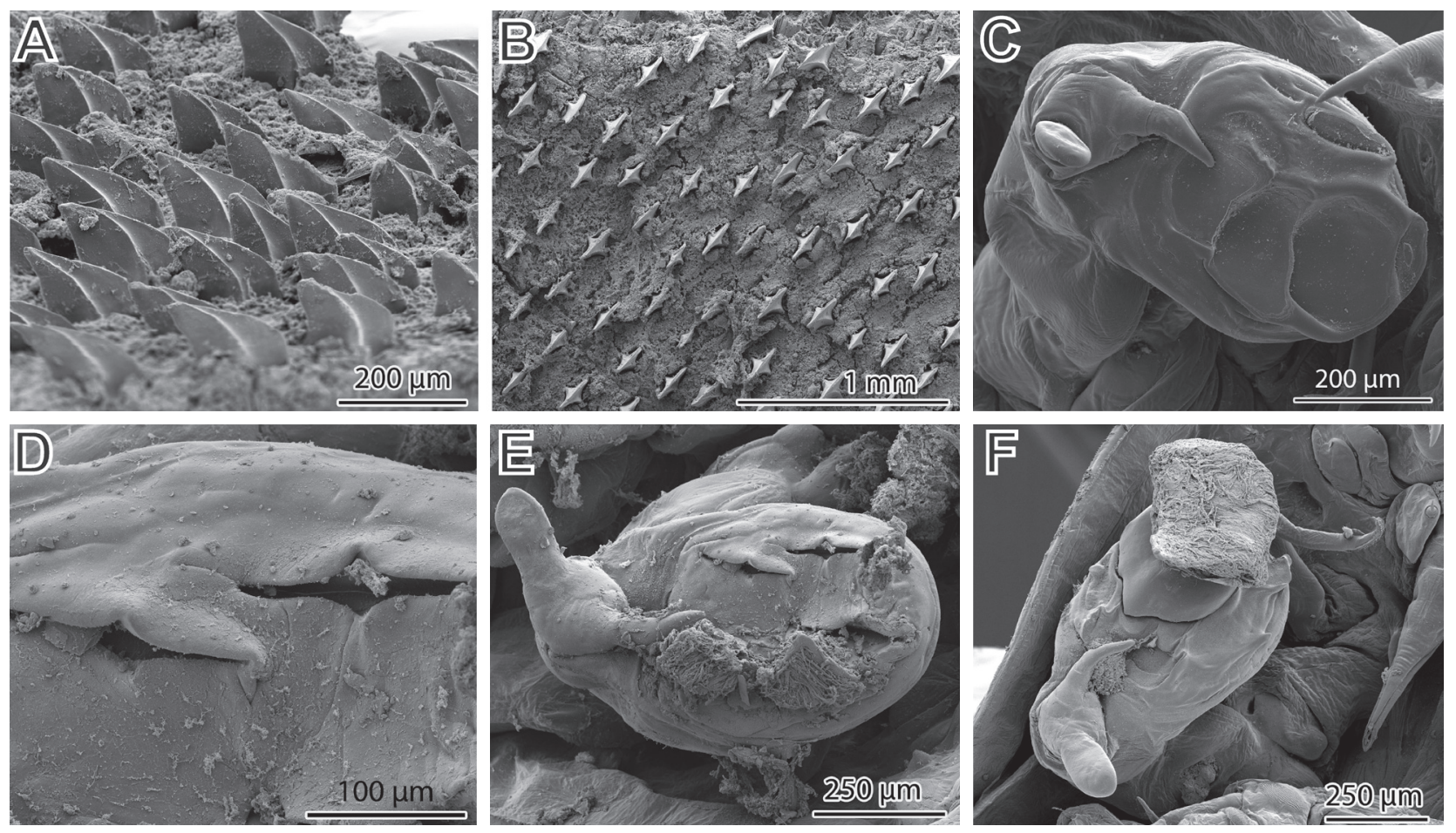

Fig. 4. Scanning electron micrographs. A - lateral view of placoid scales covering Squalus cf. megalops skin; B - surface view of kiteshaped placoid scale on Squalus cf. megalops skin; $\mathbf{C}-\mathbf{F}$ - Achteinus pinguis, adult female; $\mathbf{C}$ - maxilliped corpus with large flaccid pad, subchela bearing a flattened posterior process and terminal claw with a basal seta; $\mathbf{D}$ - longitudinally flattened kite-shaped openings visible on the corpus of the maxilliped; $\mathbf{E}$ - maxilliped with kite-shaped openings and remnants of placoid scales still attached; F - maxilliped with complete placoid scale still attached.

the attached copepod cephalothorax was observed (S.M.D. - unpubl. data) in some samples; this may appear thicker due to the erosion of the epidermis underneath the copepod rather than to actual hyperplasia.

The antennae are probably the main attachment appendages of females of species of Achtheinus and thus are also responsible for causing the most damage due to their insertion into the reticular layers of the dermis of the shark's skin. The antennae are inserted into the middle reticular layer composed of ceratotrichia and large fibre bundles (Tomita et al. 2014). Damage caused to the exterior and middle layers includes the possible compression and/or fibrosis of the connective tissue around the smooth margin of the antennae and rupture of tissue along the inner surface of the antennae armed with spikes.

Therefore, maxillipeds appear to play a secondary role in attachment by serving to keep the copepod in a position facing the oncoming water and thus keeping the antennae securely inserted in the dermis. This may be important since specimens of Achtheinus spp. are often found separately or in small numbers on their hosts, contrary to some other pandarids that are found in orderly arrangements of clustered individuals in staggered rows, which assist with the hydrodynamics of attachment (Benz 1981, Dippenaar and Jordaan 2006).

During the present study, evidence of tissue damage due to the attachment of individuals of Achtheinus pinguis to the fin edges of the hosts was observed. Since most sharks are covered with similar small placoid scales (Kemp 1977, Meyer and Seegers 2012) and the structure of the antennae and maxillipeds is similar in all species of Achtheinus (see Izawa 2010), it can be expected that the mode and effects of attachment by other species of Achtheinus to the fin edges of different sharks will be similar. However, the effects of the damage are probably negligible to the shark, especially because copepods of the genus Achtheinus are rarely found in high numbers. The most pronounced effect may be the possibility of the occurrence of secondary infection.

Acknowledgements. We thank the KwaZulu-Natal Sharks Board (KZNSB) and Marine Dynamics (Kleinbaai) for field support; Rob Leslie and Rob Cooper of the Department of Agriculture, Forestry and Fisheries (DAFF) for organising placement on board the fisheries research vessel, Africana; Beatrice Jordaan (University of Limpopo) for unfailing assistance in the collection of copepods and David Vaughan (Amanzi Biosecurity) for collecting copepods from a raggedtooth shark at Jeffreys Bay. Additionally, the Department of Biodiversity at the University of Limpopo is acknowledged for field and laboratory assistance and the Laboratory for Electron Microscopy CRB, North-West University (NWU) for laboratory assistance. We also thank the National Research Foundation (NRF) of South Africa for research support. Any opinion, findings and conclusions or recommendations expressed in this paper are those of the authors and thus the NRF does not accept any liability in this regard. 


\section{REFERENCES}

Benz G.W. 1980: Tissue proliferation associated with Nemesis lamna Risso, 1826 (Copepoda: Eudactylinidae) infestations on the gill filaments of shortfin makos (Isurus oxyrinchus Rafinesque). J. Fish Dis. 3: 443-446.

Benz G.W. 1981: Observations on the attachment scheme of the parasitic copepod Pandarus satyrus (Copepoda: Pandaridae). J. Parasitol. 67: 966-967.

Benz G.W., Adamson S.A.M. 1990: Disease caused by Nemesis robusta (van Beneden, 1851) (Eudactylinidae: Siphonostomatoida: Copepoda) infections on gill filaments of thresher sharks (Alopias vulpinus (Bonnaterre, 1758)), with notes on parasite ecology and life history. Can. J. Zool. 68: 1180-1186

Benz G.W., Deets G.B. 1986: Kroyeria caseyi sp. nov. (Kroyeriidae: Siphonostomatoida), a parasitic copepod infesting gills of night sharks (Carcharhinus signatus (Poey, 1868)) in the western North Atlantic. Can. J. Zool. 64: 2492-2498.

Benz G.W., Mollet H.F., Ebert D.A., Davis C.R., Van SomMERAN S.R. 2003: Five species of parasitic copepods (Siphonostomatoida) from the body surface of a white shark captured in Morro Bay, California. Pac. Sci. 57: 39-43.

Borucinska J.D., Benz G.W. 1999: Lesions associated with attachment of the parasitic copepod Phyllothyreus cornutus (Pandaridae: Siphonostomatoida) to interbrachial septa of blue sharks. J. Aquat. Anim. Hlth. 11: 290-295.

Cressey R. 1967: Revision of the family Pandaridae (Copepoda: Caligoida). Proc. U.S. Natl. Mus. 121: 1-133.

DippenaAR S.M., JordaAn B.P. 2006: Nesippus orientalis Heller, 1868 (Pandaridae: Siphonostomatoida): descriptions of the adult, young and immature females, a first description of the male and aspects of their functional morphology. Syst. Parasitol. 65: $27-41$

Frasca S. Jr., Kirsipuu V.L., Russell S., Bullard S.A., Benz G.W. 2004: Opercular lesions in wild black drum, Pogonias cromis (Linnaeus, 1766), associated with attachment of the sea louse Sciaenophilus tenuis (Copepoda: Siphonostomatoida: Caligidae). Acta Ichthyol. Pisc. 34: 115-127.

Froese R., Pauly D. (Eds.) 2014: FishBase. World Wide Web electronic publication, www. fishbase.org, 06/2014.

Ho J.-S. 1975: Parasitic Crustacea. In: E.D. Lane and C.W. Hill (Eds.), The Marine Resources of Anaheim Bay. California Department Fish and Game. Fish Bulletin 165: 69-72.

Humes A.G., Gooding R.U. 1964: A method for studying the external anatomy of copepods. Crustaceana 6: 238-240.

Huys R., Boxshall G.A. 1991: Copepod Evolution. The Ray Society, London, 468 pp.

IzaWA K. 2010: Resurrection of the parasitic copepod genus Achtheinus Wilson, 1908 (Siphonostomatoida, Pandaridae), with redescription of $A$. oblongus Wilson, 1908, A. dentatus Wilson, 1911, and A. pinguis Wilson, 1912 based on museum collections. Crustaceana 83: 971-995.

Kabata Z. 1979: Parasitic Copepods of British fishes. The Ray Society, London, 468 pp.

Kemp N.E. 1977: Banding pattern and fibrillogenesis of Ceratotrichia in shark fins. J. Morph. 154: 187-204.

Meyer W., Seegers U. 2012: Basics of skin structure and function in elasmobranchs: a review. J. Fish Biol. 80: 1940-1967.

Tomita T., Tanaka S., Sato K., Nakaya K. 2014: Pectoral fin of the megamouth shark: skeletal and muscular systems, skin histology, and functional morphology. PLoS ONE 9: e86205.

Cite this article as: Dippenaar S.M., Jordaan A. 2015:How females of Achtheinus spp. (Pandaridae: Siphonostomatoida) attach to their elasmobranch hosts with notes on their effects on the hosts' fins. Folia Parasitol. 62: 005. 